\title{
The Abkhazian and Mingrelian Principalities: Historical and Demographic Research
}

\author{
A. A. Cherkasov, L. A. Koroleva, S. N. Bratanovskii, A. Valleau
}

For citation: Cherkasov A. A., Koroleva L. A., Bratanovskii S. N., Valleau A. The Abkhazian and Mingrelian Principalities: Historical and Demographic Research. Vestnik of Saint Petersburg University. History, 2018, vol. 63, issue 4, pp. 1001-1016. https://doi.org/10.21638/11701/spbu02.2018.402

This article examines the historical and demographic aspects of the development of the Abkhazian and Mingrelian principalities within the Russian Empire. The attention is drawn to the territorial disputes among rulers over the ownership of Samurzakan. The sources used for this study include documents from the State archives of Krasnodar Krai (Krasnodar, Russian Federation), the Central state historical archive of Georgia (Tbilisi, Georgia), statistical data of the 1800s-1860s on Abkhazia, Mingrelia and Samurzakan, as well as memoirs and diaries of travelers. The authors came to the following conclusions: 1) the uprising of Shikh Mansur in 1785 led to the adoption of new religious rules among the population of Circassia and Abkhazia. As a result, Islam began to spread in Abkhazia. At the time, Islam did not, however, reach Samurzakan and Mingrelia. Both territories remained Christian; 2) as soon as the Abkhazian and Mingrelian principalities were annexed to the Russian Empire, the ruling princes started greatly overestimating the local population rates. They believed that there were on average at least 9-10 people per household on the territories they ruled. In reality, there were 4,7 people per household in Abkhazia and about 7 in Mingrelia; 3) the beginning of the process of decentralization, which was characteristic of the Circassian tribes, can be illustrated

Aleksandr A. Cherkasov - Doctor in History, Associate Professor, Member of the American Historical Association (Washington, United States), head of the Joint Laboratory of the International Network Center for Fundamental and Applied Research (Washington, USA) and Volgograd State University, 100, University prospect, Volgograd, 400062, Russian Federation; sochi003@rambler.ru

Александр Арвелодович Черкасов - д-р ист. наук, доцент, член Американского исторического общества (Вашингтон, США), заведующий совместной лабораторией Международного сетевого центра фундаментальных и прикладных исследований (Вашингтон, США) и Волгоградского государственного университета, Российская Федерация, 400062, Волгоград, пр. Университетский, 100; sochi003@rambler.ru

Larisa A. Koroleva - Doctor in History, Professor, Penza State University of Architecture and Construction, 28, Germana Titova str., Penza, 440028, Russian Federation; la-koro@yandex.ru

Лариса Александровна Королева - д-р ист. наук, проф., Пензенский государственный университет архитектуры и строительства, Российская Федерация, 440028, Пенза, ул. Германа Титова, 28; la-koro@yandex.ru

Sergei N. Bratanovskii - Doctor in Law, Professor, Plekhanov Russian University of Economics, 36, Stremyanny lane, Moscow, 117997, Russian Federation; bratfoot@mail.ru

Сергей Николаевич Братановский - д-р юрид. наук, проф., Российский экономический университет им. Г. В. Плеханова, Российская Федерация, 117997, Москва, Стремянный пер., 36; bratfoot@ mail.ru

Annick Valleau — PhD, University of Geneva, 24 rue du Général-Dufour, 1211, Genève 4, Switzerland; annick.valleau@unige.ch

Анник Валлоу - PhD, Женевский университет, 1211, Швейцария, Женева, ул. Генерала Дюфуpa, 24; annick.valleau@unige.ch

(c) Санкт-Петербургский государственный университет, 2018 
by the Abkhazian principality, where it was very awas accompanied by the emergence of independent estates. By contrast, Mingrelia was not subject to decentralization processes;

4) the decision to attach the Russian administration to the Sukhum Military Department of the Samurzakan pristavstvo in 1864 was taken to create an inter-confessional balance between the strongly Islamized Abkhazia and Christian Samurzakan.

Keywords: Abkhazia, Mingrelia, Principalities, Samurzakan, Russian Empire, 1800-1860s.

\section{Абхазское и Мингрельское княжества: историко-демографическое исследование}

\section{А.А. Черкасов, Л. А. Королева, С. Н. Братановский, А. Валлоу}

Для цитирования: Cherkasov A. A., Koroleva L. A., Bratanovskii S. N., Valleau A. The Abkhazian and Mingrelian Principalities: Historical and Demographic Research // Вестник Санкт-Петербургского университета. История. 2018. Т. 63. Вып. 4. С. 1001-1016. https://doi.org/10.21638/11701/ spbu02.2018.402

В статье рассматриваются исторические и демографические аспекты развития абхазского и мингрельского княжеств в составе Российской империи. Уделено внимание территориальным спорам между князьями за территорию Самурзакани. В качестве материалов использовались документы Государственного архива Краснодарского края (Краснодар, Российская Федерация) и Центрального государственного исторического архива Грузии (Тбилиси, Грузия), статистические материалы 1800-1860-х годов по Абхазии, Мингрелии и Самурзакани. Кроме того, были задействованы материалы личного происхождения: мемуары и дневники путешественников. Авторы приходят к следующим выводам: 1) восстание Ших Мансура в 1785 г. изменило религиозные правила населения Черкесии и Абхазии; в результате в Абхазии начал насаждаться ислам; в это время в Самурзакани и Мингрелии ислам распространения не получил, Самурзакань и Мингрелия оставались христианскими территориями; 2) начиная с присоединения Абхазского и Мингрельского княжеств к Российской империи владетельные князья сильно завысили численность своего населения; так, князья полагали, что у них в среднестатистической семье не менее 9-10 человек, в то время как фактически было в Абхазии - 4,7 человека, а в Мингрелии - около 7 человек; 3) в Абхазском княжестве наблюдался процесс начала децентрализации, весьма характерный для черкесских племен, который сопровождался появлением независимых сословий, в то же время в Мингрелии этот процесс не наблюдался; 4) присоединение русской администрацией к Сухумскому военному отделу территории Самурзаканского приставства в 1864 г. преследовало целью создание межконфессионального баланса между сильно исламизированной Абхазией и христианской Самурзаканью.

Ключевые слова: Абхазия, Мингрелия, княжества, Самурзакань, Российская империя, 1800-1860-е годы.

Mingrelia and Abkhazia are unique territories on the geographic map of the Caucasus. Their unique nature is interesting to researchers as the territories had been overseen by the civil governance of ruling princes until the middle of the 1860 s. This period enabled the Russian administration, among other things, to create the conditions needed to collect the most complete statistical data on these territories. In addition, rulers of Mingrelia and Abkhazia differed from each other in their political affiliations. For example, Prince Mikhail Shervashidze, the ruler of Abkhazia, pursued a policy designed to strengthen 
his personal power, which eventually resulted in his collaboration with Turkish troops during the Crimean War ${ }^{1}$, and later - in his removal from Abkhazia. By contrast, rulers of Mingrelia, Princes Levan, David and Nikolai Dadiani were pro-Russian supporters. The reasons that could be attributed to this stance are numerous. However, the primary cause was related to the territorial dispute over Samurzakan (modern Gali district of Abkhazia). The end of the Caucasian War in 1864 and the return to normal social life in the region made the issue of special status of Abkhazia and Mingrelia come to the fore on the agenda. It is worth mentioning that this special status precluded the possibility of carrying out a reform on the abolition of serfdom in the principalities.

It is also necessary to note that the Abkhazian and Mingrelian Principalities were not the only territories that had their own rulers. For example, in 1810 Guria accepted the protectorate of the Russian Empire. After the death of Major-General Mamia Gurieli in 1827, the Prince of Guria, his 8-year-old son David became the heir. Based on the proposal of General Yermolov, a council of local princes led by Princess Sophia, the wife of the late ruler, was established to manage the principality until David came of age. Shortly after the council was created, Princess Sophia extended her power to act unrestrictedly while administering the territory and perpetrated hostile acts against Russia. During the Russo-Turkish War, on 2 October 1828, she fled to Turkey with some of the Gurian princes. In September 1829, Princess Sophia deceased in Trebizond. Guria became part of the Russian Empire. In the same year, the Principality of Guria was eliminated ${ }^{2}$. In addition to the Principality of Guria, there was also the Principality of Svaneti.

Materials for the study were documents discovered in the State Archives of the Krasnodar Territory (Krasnodar, Russian Federation), the Central State Historical Archives of Georgia (Tbilisi, Georgia), as well as statistical materials of the 1800-1860s on Abkhazia, Mingrelia and Samurzakan. Furthermore, we used individual materials of personal origin, such as memoirs and travel diaries.

In order to address research problems both general scientific methods (analysis and synthesis, concretization, generalization) and traditional methods of historical analysis were used. In this article, we applied the historical and situational methods, which implies the study of historical facts in the context of the examined period and in conjunction with related events and facts. The use of methods of demographic statistics was determined by the need to reconstruct the population size and its composition as there are no complete data on these characteristics available. A review of demographic patterns and socio-demographic connections was an important step in defining the size of the social estates in Abkhazia and Mingrelia, as well as in Samurzakan, the so-called "disputed territory".

Key sources for research included: "The collection of statistical information about the Caucasus" 3 , a collection of articles "Documents on the history of Georgia", the Collection of statistical data on the Transcaucasian region", as well as "Acts of the Caucasus archaeographic commission" (AKAK). It is known that the territory of the Black Sea peoples was not a target of statistical data collection in the period under review. Therefore, we resorted

1 Vazerova A. G., Gurbanov R. A., Micky N. V. The Crimean War (1855-1856): the Combat Operations in Rioni Region // Bylye Gody. 2017. Vol.43, iss. 1. P.116-117.

2 Akty Kavkazskoi arkheograficheskoi komissii. Vol. 8. Tiflis, 1881. P. 440-441.

3 Sbornik statisticheskikh svedenii o Kavkaze. Vol. I / ed. by N. I. Voronova. Tiflis, 1869.

${ }^{4}$ Dokumenty po istorii Gruzii. Ser. 2. Vol. 1 / ed. by Sh. K. Chkhetiya. Tbilisi, 1954.

${ }^{5}$ Sbornik statisticheskikh svedenii po Zakavkazskomu kraiu / ed. by E. Kondratenko. Ch. 1. Tiflis, 1902 . 
to using diary entries and recollections of travelers who lived among mountaineers. These personal accounts contained information of value to our research. Great importance can be attached to the works by M. Peisonel' ${ }^{\prime}$, J. Chardin ${ }^{7}$, T. Lapinskii ${ }^{8}$. The available statistical materials on the population of Mingrelia and Abkhazia during their accession to Russia proved to be rather inaccurate. Although the primary reason for this is that no fullfledged population censuses were conducted at the time, the information on the number of families can be instrumental in counting operations. It is also important to note that we have already made an attempt to have a closer look at the Abkhazian aristocratic society in the 1810 s- $1860 s^{9}$. In the current study, we adjusted several controversial propositions, including those related to Samurzakan. In addition, in 2017, a team of authors, consisting of P. A. Byshkov et al. tried to provide an analysis of the economic environment in the Abkhazian principality as compared to the former Kingdom of Kartli-Kakheti ${ }^{10}$.

A significant constituent of the policy adopted by the rulers in the Northwest Caucasus was the seizure of new territories. By seizing territories, rulers were able to enhance trafficking in people. Abkhazia was located between Mingrelia and territories controlled by Circassian tribes. Expansion plans into the area of Circassian tribes seemed to be rather challenging because of their militant ways and persistent raids on Abkhazia. Importantly, both Abkhazia and Circassian tribes were immature societies and economies in comparison with Mingrelia. In the middle of the $17^{\text {th }}$ century, merchants rarely took the risk of approaching these shores for trade. For example, a French traveler, Jean Chardin, who visited Mingrelia in 1672, wrote that trade with Circassians and Abkhazians was carried out with all safeguard measures: merchant ships would send boats crewed by armed men to do business. They made sure that same number of highlanders would show up at the meeting point where the boat moored. If they were outnumbered by the highlanders, they would immediately sail away. Nevertheless, Chardin underscored that Abkhazia was more developed than the territories ruled by Circassian tribes ${ }^{11}$. This determined the direction of Abkhazia's geopolitical ambitions towards richer regions, namely, Mingrelia. Speaking of the borders between Mingrelia and Abkhazia, Jean Chardin noted that Mingrelia was once protected from Abkhazians by a 60 miles long wall. This was the so-called "Great Abkhazian Wall" that ran along the Kelasuri river, $5 \mathrm{~km}$ east of present-day Sukhum. By the time Chardin mentioned it, the wall had already half crumbled, and a safeguard against Abkhazians was created by impenetrable forests ${ }^{12}$. At the same time, Chardin pointed out that the border between Abkhazia and Mingrelia was located along the Kodur river. We can suppose that he meant the Kodor river that flows $20 \mathrm{~km}$ east of Sukhum. When describing relations between the Mingrelian and Abkhazian principalities, Chardin cites an interesting case. During Chardin's stay in Mingrelia, the principality was attacked by Turks and Gurians, and to protect his territory from the enemy raid, the Mingrelian prince in-

\footnotetext{
${ }^{6}$ Peisonel' M. Issledovanie torgovli na cherkessko-abkhazskom beregu Chernogo moria v 17501762 gg. Krasnodar, 1927.

7 Puteshestvie Shardena po Zakavkaz'iu v 1672-1673 gg. Tiflis, 1902.

8 Lapinskii T. Gortsy Kavkaza i ikh osvoboditel'naia bor'ba protiv russkikh. Nal'chik, 1995.

9 Cherkasov A.A., Ivantsov V.G., Shmigel M., Molchanova V.S. Demographic characteristics of the Aristocratic Abkhazia in 1800-1860 years // Bylye Gody. 2016. Vol.39, iss. 1. P. 53-66.

10 Byshkov P. A., Novitskaya L. Y., Artemova S. F. The evolution of social organization in Abkhazia and Samurzakano in 1810-1870 // Bylye Gody. 2017. Vol. 44, iss. 2. P. 445-450.

11 Puteshestvie Shardena... P. 19-20.

12 Ibid. P. 20.
} 
vited the Abkhazian prince with his troops. When he reached the border with Mingrelia, the Abkhazian prince promised that he would not attack Mingrelians, but as soon as he crossed the border, he began burning and sacking Mingrelian settlements. In total, the Abkhazians took about 1.2 thousand Mingrelians captive ${ }^{13}$.

In 1723, a map drawn by French royal cartographer Guillaume Delisle was published in Paris-based cartographic album "Atlas de Géographie" (fig. 1). The map is known to have been created based on trips to the Caucasus by French ambassadors and travelers. Later, the map was reprinted in the Netherlands in 1742. According to this document, the border between Abkhazia and Mingrelia ran along the Kelasuri river. Therefore, we can assume that this $15 \mathrm{~km}$-forest zone between the rivers Kelasuri and Kodor formed the natural protection for Mingrelia against Abkhazia.

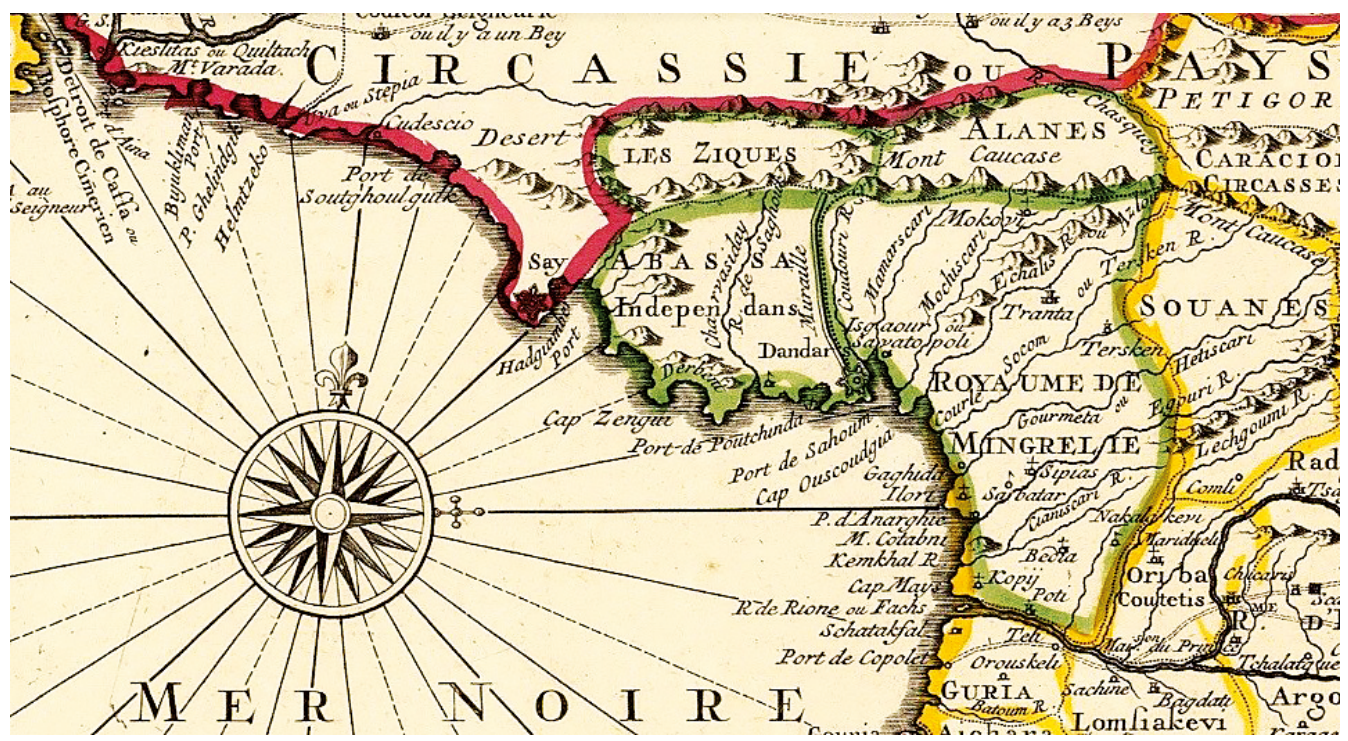

Fig. 1. The map of Abkhazia and Mingrelia as of 1723

According to the merchant M. Peisonel, who visited the Abkhazian coast in 17501762, Abkhazians considered themselves pious Christians until the middle of the $18^{\text {th }}$ century ${ }^{14}$. The situation changed in 1785 when a civil war, triggered by Shikh Mansur's insurgency, broke out in Circassia. The war transformed the Circassian state structure: a number of major aristocratic tribes (Shapsugs, Natukhais, and Abadzekhs) became democratic. The entire territory of Circassia and Abkhazia experienced changes in religious rules, and the ban on the Quran was lifted ${ }^{15}$. This encouraged the launch of a massive campaign to discredit Christianity, which went together with persecutions of the Christian and pagan clergy ${ }^{16}$. Already in the 1840 s, the population in the so-called "inner Ab-

13 Puteshestvie Shardena... P. 104, 111.

14 Peisonel' M. Issledovanie torgovli... P. 29.

15 Cherkasov A. A., Menkovsky V.I., Ivantsov V. G., Ryabtsev A. A., Molchanova V. S., Natolochnaya O. V. The "Nobility" and "Commoners" in Ubykh Society: The Reasons behind the Social Conflict // Bulletin of the Georgian Academy of Sciences. 2014. Vol. 8, N 3. P. 64-72.

${ }^{16}$ Lapinskii T. Gortsy Kavkaza i ikh osvoboditel'naia bor'ba protiv russkikh. Nal'chik, 1995. P. 103. 
khazia" - that is to say the Pitsundsky, Drandsky and Tsebeldinsky districts - preserved Christianity within half-ruined churches. Samurzakan was not part of Abkhazia at the time. This is proved by the fact that Islam did not spread among Samurzakans, meaning the territory was not under Abkhazia's jurisdiction.

In the early $19^{\text {th }}$ century, the process of incorporating the Mingrelian and Abkhazian principalities into the Russian Empire began. It is important to note that both Abkhazia and Mingrelia were aristocratic territories between the 1800s and 1860s, which were governed by ruling princes. Mingrelia became part of Russia in 1803, while Abkhazia - in 1810.

What were the principalities like at the time of their accession? In 1803, that is when the principalities were integrated into Russia, the population of Mingrelia, headed by Prince Levan Dadiani, amounted to 12 thousand households (60 thousand men $)^{17}$. According to the 1810 data, the Abkhazian principality, led by Prince Sefer Ali Bey, had 5 thousand households ( 25 thousand men $)^{18}$. Based on this initial data, we can add to the number of men an equal number of women and determine an approximate population size. Following this logic, we can suggest that the average household in both Abkhazia and Mingrelia consisted of 10 people. However, the question of gender balance requires some clarifications. Let us look at the statistics (table 1).

Table 1. The population of the Abkhazian principality on the basis of gender according to the 1865 data $^{*}$

\begin{tabular}{|l|c|c|c|}
\hline \multirow{2}{*}{\multicolumn{1}{c|}{ Districts }} & \multicolumn{3}{c|}{ Population } \\
\cline { 2 - 4 } & Male & Female & Total \\
\hline Pitsundsky (Bzybsky) & 14,183 & 12,183 & 26,366 \\
\hline Drandsky (Aybzhuysky) & 8,824 & 7,681 & 16,505 \\
\hline Tsebeldinsky & 5,368 & 4,977 & 10,345 \\
\hline Total & 28,375 & 24,841 & 53,216 \\
\hline
\end{tabular}

* The table does not contain data on Samurzakan because the region was not part of the Abkhazian principality.

B a sed on: Sbornik statisticheskikh svedenii o Kavkaze. Vol. I / ed. by N. I. Voronova. Tiflis, 1869. P.39.

Based on table 1, we can see that females accounted for $46,7 \%$, and males for $53,3 \%$ of the Abkhazian population. One of the reasons which can explain the identified disproportion between female and male birth rates is the slave trade. The slave trade had been one of the key sources of income for the coastal and mountain inhabitants over several centuries. Among the slaves exported to Turkey and Persia, the majority were females, from infants to 20 -year-old women. Let us illustrate this observation with the following example. In July 1810, a Russian war corvette intercepted a Turkish slave ship in the Gelendzhan-Kale area (Circassian coast). In addition to Russian and Circassian captives, it carried 41 Abazins on board ( 5 men and 36 women). The average age of 36 women was 14 ,

${ }^{17}$ Akty Kavkazskoi arkheograficheskoi komissii. Vol. 4. Tiflis, 1870. P. 953.

18 Ibid. 
$8^{19}$. An important detail is that all women had Turkish names, which means that people were bought in the Muslim areas of internal Abkhazia.

Prince Mikhail Shervashidze, the ruler of Abkhazia, who was in charge of the civil administration of the territory, carried on slave trade with Turkey essentially throughout the entire Caucasian War. He sold abroad about 400 boys and girls annually, i. e. about $1 \%$ of the population of the Abkhazian principality ${ }^{20}$. The fact that prince Shervashidze was involved in human trafficking was confirmed by Major Kirillov, a representative of the Russian administration, who reported that such a trade was conducted almost openly ${ }^{21}$.

The gender situation in Mingrelia was similar to that in Abkhazia (table 2).

Table 2. The population of the Mingrelian principality on the basis of gender according to 1865 data

\begin{tabular}{|l|c|c|c|}
\hline \multirow{2}{*}{\multicolumn{2}{c|}{ Districts }} & \multicolumn{3}{c|}{ Population } \\
\cline { 2 - 4 } & Male & Female & Total \\
\hline Lechkhumsky & 14,236 & 10,916 & 25,152 \\
\hline Senaksky & 47,143 & 37,698 & 84,841 \\
\hline Zugdidsky & 38,735 & 32,064 & 70,799 \\
\hline Total & 100,114 & 80,678 & 180,792 \\
\hline
\end{tabular}

B a sed on: Sbornik statisticheskikh svedenii o Kavkaze. Vol. I / ed. by N. I. Voronova. Tiflis, 1869. P.39.

From table 2 it can be inferred that females accounted for $44,6 \%$, and males for $55,4 \%$ of the Mingrelian population. A similar situation can be noticed in Samurzakan. For example, the data for 1867 suggests that 11,795 men and 10,063 women lived in Samurzakan $^{22}$. Hence, in Samurzakan, the percentage of men was $54 \%$, whereas women represented $46 \%$ of total population. Thus, on average, the territory of Abkhazia, Mingrelia and Samurzakan was home to $55 \%$ of men and only to $45 \%$ of women.

Considering the gender imbalance, according to which, there were 9 women for 10 men, we can draw the following conclusion: the princes believed that the households of their subjects included a minimum of 9 people.

However, let us turn to the data available on this topic. For example, as of 1867, Abkhazia’s Pitsundsky and Drandsky districts had 9,176 households with a total population of 42,988 people, i. e. approximately 4,7 people per household ${ }^{23}$. At the same time, in Samurzakan, Abkhazia's neighbor, the average household consisted of 6,2 people ${ }^{24}$.

Amuch smaller size of households in the Muslim part of Abkhazia can be explained by a number of factors: child marriages for women, which in most cases led to infertility

${ }^{19}$ Cherkasov A. A., Ivantsov V. G., Smigel M., Molchanova V.S. The List of Captives from the Turkish Vessel Belifte as a Source of Information on the Slave Trade in the North-Western Caucasus in the Early $19^{\text {th }}$ century // Annales : Anali za istrske in mediteranske studije. Series historie et sociologia. 2017. Vol.27, iss. 4. P. $858-859$.

20 TsGIAG. F. 4. Op. 1. D. 3632. L. 4-5 (Tsentralniy gosudarstvennii istoricheskiy arkhiv Gruzii).

${ }^{21}$ Ibid. L.7.

22 Sbornik statisticheskikh svedenii o Kavkaze. Vol. I. P. 39.

23 Ibid. P. 39.

24 Ibid. 
or early impotence, as well as to divorce. In addition, Muslim families recorded a higher percentage of deaths, caused by almost complete disregard for medicine ${ }^{25}$, and by the slave trade. Another essential contributor to the mortality rate was the blood feud, an established practice among Circassians and Abkhazians. For example, in Abkhazia's mountainous region Tsebelde, the Marshani, a family of local rulers, was involved in a series of conflicts in 1844 . As a result, they suffered 17 casualties just in a few days ${ }^{26}$.

What was the situation in Mingrelia? While there were 4,7 people per household in Abkhazia and 6.2 in Samurzakan, these figures were even higher in different districts of Mingrelia and reached 7.32 people per household (table 3 ).

2728

Table 3. The average family size in Mingrelia by districts according to the data for 1859-1860

\begin{tabular}{|l|c|c|c|c|}
\hline Districts & No. of smokes & $\begin{array}{c}\text { Size of } \\
\text { population }\end{array}$ & $\begin{array}{c}\text { Average no. of } \\
\text { people per smoke }\end{array}$ & \% of population \\
\hline Lechkhumsky & $3,528^{* *}$ & 25,152 & 7,12 & 13,9 \\
\hline Senaksky & 11581 & $84,841^{27}$ & 7,32 & 46,9 \\
\hline Zugdidsky & 10,602 & $70,799^{28}$ & 6,67 & 39,2 \\
\hline Total in Mingrelia & 25,711 & 180,792 & 7,03 & 100 \\
\hline
\end{tabular}

${ }^{*}$ Families were counted by the number of cooking hearths, i.e. by the smoke they produced.

$* *$ The table contained an error in the number of smokes. It should be 3,528, not 3,228.

B a se d on: Dokumenty po istorii Gruzii. Ser. 2. Vol. 1 / ed. by Sh. K. Chkhetiya. Tbilisi, 1954. Suppl. $1-3$.

The data on the number of members per household in the Zugdidsky district $(6,67$ people) is very close to the figures on the neighboring Okumsky district (Samurzakan), that is to say 6,25 people. This leads us to the assumption that the slave trade was not conducted in Samurzakan. The decrease in the population was linked to sporadic attacks by Circassians, Jigets and Abkhazians on Samurzakan designed to take captives.

To sum up, there were 4,7 people per household in Abkhazia, 6,2 in Samurzakan and about 7 in Mingrelia. This, in turn, helps us to determine the approximate population of Abkhazia and Mingrelia at the time they were incorporated into the Russian Empire. For example, the estimated population of the Abkhazian principality was supposed to be 23, 5 thousand people. The Abkhazian historiography refers to 100-150 thousand people ${ }^{29}$. Earlier, we mentioned that the population of Abkhazia in 1807 amounted to 30 thousand people. Thus, the figures were roughly the same ${ }^{30}$. At the same time, the population of Mingrelia, combined with that of Samurzakan, amounted to about 84 thousand people.

25 Ibid. P. 37.

26 GAKK. F. 261. Op. 1. D. 833. L. 22. (Gosudarstvenniy arkhiv Krasnodarskogo kraja)

27 The table contained an error in the number of people living in the region. It should be 84,841 , not 86,174 .

28 The table contained an error in the number of people living in the region. It should be 70,799, not $71,156$.

${ }^{29}$ Dzidzariya G. A. Narodnoe khozyaistvo i sotsial'nye otnosheniia v XIX v. (do krest'yanskoi reformy 1870 g.). Sukhumi, 1958.

30 Cherkasov A.A., Ivantsov V.G., Shmigel M., Molchanova V.S. Demographic characteristics of the Aristocratic Abkhazia in 1800-1860 years // Bylye Gody. 2016. Vol.39, iss. 1. P. 63. 
In the second half of the $17^{\text {th }}$ century, French traveler Jean Chardin wrote in his account about Mingrelia that the upper class had the right to the life and property of their peasant subjects, could do "whatever they want with them, take women, children, sell them at random and use them for anything they please" 31 . Describing the types of taxes and duties that the peasants paid to princes and nobles, Chardin noted that the wealth of the upper class in Mingrelia depended on the number of its peasants ${ }^{32}$. Importantly, Mingrelia shared this similarity not only with Abkhazia, but almost with the entire Caucasus.

We should briefly review the demographic situation in Abkhazia and the division of society into social classes (estates). The Civil War of 1785 did not abolish the Abkhazian aristocratic society, but merely introduced certain adjustments to it. For example, there were sizeable independent estates in Abkhazia - 14,7\% of the population (table 4 ). Nevertheless, the percentage of dependent people exceeded $3 / 4$ of the population.

33

Table 4. The Abkhazian aristocratic society including Samurzakan as of $\mathbf{1 8 6 5}$

\begin{tabular}{|c|c|c|}
\hline Estates & Total population & In $\%$ of the total number \\
\hline \multicolumn{3}{|c|}{ Privileged estates } \\
\hline Princes & 1,639 & 2,1 \\
\hline Nobles, incl. personal nobles & 4,826 & 6,1 \\
\hline Total & 6,465 & 8,2 \\
\hline \multicolumn{3}{|c|}{ Independent estates } \\
\hline Free residents (ankhave) not paying taxes & 9,094 & 11,5 \\
\hline Mingrelians & 429 & 0,5 \\
\hline Azats (not paying taxes to anyone) & 2,105 & 2,7 \\
\hline Total & 11,628 & 14,7 \\
\hline \multicolumn{3}{|c|}{ Dependent estates } \\
\hline Free residents on the princely lands ${ }^{33}$ (pioshi) & 16,943 & 21,4 \\
\hline Free residents (ankhave) on the lands of other princes & 25,381 & 32,0 \\
\hline Obrok (taxed) peasants (moinalepioshi) & 1,400 & 1,8 \\
\hline Peasants (agyrva), incl. subject peasants & 15,223 & 19,2 \\
\hline Slaves (akhashala) & 2,155 & 2,7 \\
\hline Total & 61,102 & 77,1 \\
\hline Total of people & 79,195 & 100,0 \\
\hline
\end{tabular}
$1-3$.

B a se d o n: Dokumenty po istorii Gruzii. Ser. 2. Vol. 1 / ed. by Sh. K. Chkhetiya. Tbilisi, 1954. Suppl.

\footnotetext{
31 Puteshestvie Shardena... P. 30.

32 Ibid.

33 This refers to the lands of ruling Shervashidze princes.
} 
The difference between Mingrelia and Abkhazia was that Shikh Mansur's insurgency and the civil war in Circassia produced no effect on Mingrelia. In other words, Mingrelia continued to be an aristocratic society. In this connection, the Mingrelian society was characterized by a clear division between privileged and dependent estates (table 5).

34

Table 5. The Mingrelian aristocratic society based on the cameral description of 1859-1860

\begin{tabular}{|l|c|c|}
\hline \multicolumn{1}{|c|}{ Estates } & Total population & In \% of the total number \\
\hline \multicolumn{2}{|c|}{ Privileged estates } & 0.9 \\
\hline Princes (tavadi) & 1,712 & 1.6 \\
\hline Clergymen & Dependent estates & \\
\hline \multicolumn{2}{|c|}{2,953} & 12,842 \\
\hline Nobles (aznauri), incl. personally free nobles & 284 & 0.1 \\
\hline Priests & 20,723 & 11.5 \\
\hline Peasants: owned by princes & $22,008^{34}$ & 12.2 \\
\hline owned by the church & 118,143 & 65.4 \\
\hline owned by landlords & 2,127 & 1.1 \\
\hline Total of people & 176,127 & 97.5 \\
\hline
\end{tabular}

B a s ed on: Dokumenty po istorii Gruzii. Ser. 2. Vol. 1 / ed. by Sh. K. Chkhetiya. Tbilisi, 1954. Suppl. $1-3$.

Significantly, the independent estates only included the so-called Secular Clergy: priests who were exempted from serfdom in 1841 at the behest of the ruler of Mingrelia, Prince David Dadiani ${ }^{35}$.

Thus, in the Abkhazian principality, the social structure of the population presents the first signs of the decentralization process in its aristocratic society and is characterized by sizeable independent estates. Our opinion is that the events behind these trends can be traced back to the 1785 events which led to Abkhazia changing its religious rules.

However, let us return to the borders between Abkhazia and Mingrelia. Until the early $19^{\text {th }}$ century, the territory of Mingrelia became increasingly smaller. For example, in 1834, Samurzakan was part of Mingrelia. The border between Georgia and Abkhazia was created along the Aaldzga river (today called the Galidzga). This means that for over 100 years the lands stretching over $50 \mathrm{~km}$ along the seashore from Kelasur to Aaldzga had been separated from the territory of Mingrelia.

In 1834, prince Levan Dadiani, ruler of Mingrelia, informed the Russian administration that the runaway Mingrelian brigands had a safe haven in Abkhazia in the Shuako-

34 The table based on the cameral description of the Senaksky district mixed up the columns of peasants that belonged to landlords and church.

35 Dokumenty po istorii Gruzii. Suppl. 1-3. 
peli village. From there, they perpetrated attacks on Mingrelia, killed and seized people in order to sell them as slaves to Turkey. For example, in 1832, Prince Guza Tugu-Shvili, who ran away from Mingrelia, robbed a farmstead, killed a peasant and sold five people to Turkey ${ }^{36}$. On 31 October 1833, 14 people were abducted from Samurzakan. During the attack, Akirtava, a nobleman, and one of his subjects were killed ${ }^{37}$.

In 1834, the ruling prince of Abkhazia, M. Shervashidze, arrived at the banks of the river in Ilori (Mingrelia), forced villagers to swear an oath and seized amanats (hostages). Once the news reached the Russian administration, the ruler of Abkhazia was compelled to return the amanats and to refrain henceforth from such wrongful doings ${ }^{38}$. In addition, the Russian administration knew that Shervashidze's younger son, Prince Alexander, had departed to Tsebeldinians (mountain Abkhazians) and organized there a gang to rob Samurzakan villages ${ }^{39}$. It is important to note that the ruler of Abkhazia also tried to engage Jigets in such attacks ${ }^{40}$.

Along with the claims on certain areas of Samurzakan, laid by the Abkhazian ruler in the 1840-1850s, the ruler of Svanetia, Cornet of the Life Guards of the Cossack regiment, Prince Constantine Dadeshkeliani, had also pressed claims on the mountainous part of the territory ${ }^{41}$. The dispute over the grazing rights in the area was long accompanied by raids mounted by Svanetia, with significant bloodshed on both sides. Eventually, Svans, being the stronger side, forced Samurzakans to pay tribute for the permission to graze livestock in their territory ${ }^{42}$. In 1852, the ownership maps were modified to the advantage of the ruler of Svanetia ${ }^{43}$.

In 1840, the Russian administration, aiming to end the dispute between Mingrelia and Abkhazia, withdrew Samurzakan from Mingrelia. This step resulted in the foundation of a Samurzakan pristavstvo (roughly "oversight commission") ${ }^{44}$. We believe that the creation of the pristavstvo can be perceived as a buffer zone established between Abkhazia and Mingrelia. Hence, in the event of an attack by the ruler of Abkhazia, he would not strike Mingrelia, but rather the territory directly controlled by Russians.

In 1840, the Samurzakan militia was engaged in joint operations with the Russian troops, designed to pacify Dal in the territory of mountainous Abkhazia. The militia notched up success after success leading to the Russian command awarding a banner to Samurzakan. A similar decoration had already been granted to Abkhazia and Mingre$\operatorname{lia}^{45}$

The red banner, granted in 1841, bore a legend: "To the militia of our faithful Samurzakan people for the service rendered in 1840 in establishing order in Dal" (fig. 2).

In 1848, the Samurzakan district, managed by the department of the chief of the Black Sea Cordon Line, was included in the Kutaisi governorate ${ }^{46}$.

\footnotetext{
36 TsGIAG. F. 2. Op. 1. D. 3481. L.2.

37 Ibid. L. 25.

38 Akty Kavkazskoi arkheograficheskoi komissii. Vol. 8. Tiflis, 1881. P. 449.

39 Ibid.

40 Ibid. P. 453.

41 GAKK. F. 260. Op. 1. D. 1007. L. 1-4.

${ }^{42}$ GAKK. F. 260. Op. 1. D. 1007. L. 8-9.

43 Ibid. L. 17-18.

44 Akty Kavkazskoi arkheograficheskoi komissii. Vol. 12. Tiflis, 1904. P. 332.

45 Akty Kavkazskoi arkheograficheskoi komissii. Vol. 9. Tiflis, 1884. P. 497.

${ }^{46}$ Akty Kavkazskoi arkheograficheskoi komissii. Vol. 12. P.332; GAKK. F. 260. Op. 1. D. 757. L. 3.
} 


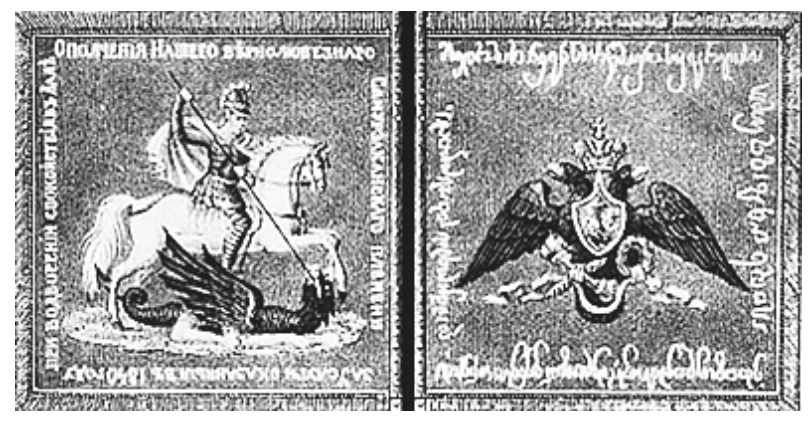

Fig. 2. The banner of the Samurzakan militia

In June 1864, the Abkhazian principality was abolished. On 14 August 1864, a new administrative and territorial unit was set up, leading to reorganizing a number of adjacent territories: the Sukhum Military Department. The new administrative unit included Abkhazia, as well as the Tsebelde and Samurzakan pristavstvos ${ }^{47}$. From our point of view, attaching Samurzakan to the Sukhum Military Department might have been an attempt of achieving an artificial balance between religious confessions in the region.

For example, according to the 1865 figures, the Sukhum Military Department reported about 37 thousand Christians and 42 thousand Muslims ${ }^{48}$. It is also known that by 1865 the population of Samurzakan (Okumsky district) stood at almost 22 thousand people ${ }^{49}$. Hence, there were 15 thousand Christians and 42 thousand Muslims in the Abkhazian principality, representing $26,3 \%$ and $73,7 \%$ of the population respectively by the time of its abolition. In other words, Muslims accounted for $3 / 4$ of the Abkhazian population. As the Sukhum Military District was established, and Christian Samurzakan was integrated with its 22 thousand people, the confessional structure of the Sukhum Military Department obtained a more balanced division with 37 thousand Christians and 42 thousand Muslims. Percentages were $46,8 \%$ of Christians and 53,2 \% of Muslims. However, as early as 1866, the so-called Lykhny uprising broke out in the Muslim part of Abkhazia. The insurgents suffered minor casualties, but the outcome was 14 thousand Abkhazian Muslims leaving for Turkey. As a result, the Sukhum Military Department was left with 37,2 thousand Christians and 27,7 thousand Muslims ${ }^{50}$ and was thus composed by $57,3 \%$ of Christians and by $43,7 \%$ of Muslims. Accordingly, the confessional portrait of the territory changed only 3 years after the Abkhazian principality was abolished. The key factor behind this trend was the accession of Samurzakan.

Unlike Abkhazia, Mingrelia was a mono-confessional territory. We can provide statistical data below on the religious beliefs of the population, available in the Russian Imperial Census of 1897 (table 6).

The figures in table 6 indicate that Orthodox population of Mingrelia amounted to $99 \%$. There is no reason to believe that the situation here was different in the 1860 s. Thus, the Mingrelian principality was a territory with one dominant religion - Christianity.

\footnotetext{
47 Dokumenty po istorii Gruzii... P. 565.

48 Sbornik statisticheskikh svedenii o Kavkaze. Vol. I. P. 12 Suppl.

49 Ibid. P.39. Suppl.

50 Ibid.
} 


\begin{tabular}{|c|c|c|c|c|c|c|c|c|}
\hline Districts & 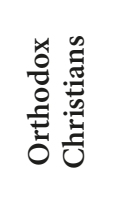 & 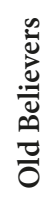 & 跣 & 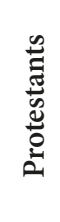 & 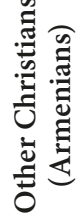 & $\frac{\stackrel{\Xi}{\Xi}}{\stackrel{\Xi}{\Xi}}$ & 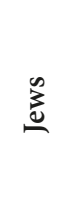 & 荧 \\
\hline Lechkhumsky & 47,273 & - & - & - & 160 & 12 & - & 47,910 \\
\hline Senaksky & 113,698 & 7 & 333 & 144 & 403 & 278 & 911 & 115,774 \\
\hline Zugdidsky & 114,779 & 4 & 16 & 9 & 20 & 145 & 2 & 114,975 \\
\hline Total & 275,750 & 11 & 349 & 153 & 583 & 435 & 913 & 278,659 \\
\hline
\end{tabular}

B a sed on: Sbornik statisticheskikh svedenii po Zakavkazskomu kraiu / ed. by E. Kondratenko. Ch. 1. Tiflis, 1902. P. 254.

The Mingrelian principality was abolished on 17 April 1867, and its territory comprising three districts - Zugdidsky, Lechkhumsky and Senaksky — was attached to the Kutaisi governorate ${ }^{51}$.

School education in these principalities also deserves attention. For example, the first school in Mingrelia was opened once the consent of the ruling prince was obtained in 1829. As of 1834, 41 pupils studied in the Mingrelian public school ${ }^{52}$. In Samurzakan, the first school was inaugurated in 1851, while only in 1860 this was achieved in the Abkhazian principality ${ }^{53}$, when the ruling prince stepped back from his administrative duties for health reasons.

Interesting insights can be received through the comparison of rates related to serious criminal offenses, i.e. murders in Abkhazia (including Samurzakan) and Mingrelia (table 7). The statistical data were collected in a later period - between 1894 and 1898.

Based on table 7, it is possible to conclude that Abkhazia was a leader in the murder rate in 1894, 1895 and 1897. In 1896, the number of murders was the same in the two regions. Only in 1898 there were more people killed in Mingrelia. The average homicide rate in Abkhazia was of 25.4 people annually. Conversely, this indicator stood at 23,4 in Mingrelia. However, we should take into account that the population of Abkhazia, as shown in the 1897 census (Sukhum district and the City of Sukhum) numbered 100,489 people, while Mingrelia had a population of 286,348 people $^{54}$. In other words, there was one murder per 791 people in Abkhazia and one per 2,447 in Mingrelia. Per capita recalculation suggests that the homicide rate in Abkhazia was as much as 310 percent higher than in Mingrelia. A significant consideration here is that by the end of the $19^{\text {th }}$ century, the high crime rates in the region could not be justified by attacks on behalf of hostile tribes. This

${ }^{51}$ Dokumenty po istorii Gruzii... P. 469.

52 Shevchenko N.A., Vidishcheva E. V., Emelyanova O. V. The Establishment of the System of Public Education in the Caucasus (1802-1917 years): the Characteristic Features // Bylye Gody. 2016. Vol. 40, iss. 2. P. 365 .

${ }^{53}$ Materialy po istorii osetinskogo naroda: sbornik dokumentov po istorii zavoevaniia osetin russkim tsarizmom / ed. by V.S. Gal'tsev. Ordzhonikidze, 1942. Vol. II. P. 94.

${ }^{54}$ Sbornik statisticheskikh svedenii po Zakavkazskomu kraiu... P. 18. 
Table 7. The homicide rate in Abkhazia and Mingrelia from 1894 to $1898^{\star}$

\begin{tabular}{|c|c|c|c|c|c|c|c|c|c|c|c|c|c|}
\hline \multirow{3}{*}{ Territory } & \multicolumn{10}{|c|}{ Year } & \multirow{2}{*}{\multicolumn{3}{|c|}{ Total }} \\
\hline & \multicolumn{2}{|c|}{1894} & \multicolumn{2}{|c|}{1895} & \multicolumn{2}{|c|}{1896} & \multicolumn{2}{|c|}{1897} & \multicolumn{2}{|c|}{1898} & & & \\
\hline & $\mathrm{m}$ & $\mathrm{f}$ & $\mathrm{m}$ & $\mathrm{f}$ & $\mathrm{m}$ & $\mathrm{f}$ & $\mathrm{m}$ & $\mathrm{f}$ & $\mathrm{m}$ & $\mathrm{f}$ & $\mathrm{m}$ & $\mathrm{f}$ & total \\
\hline Abkhazia & 21 & - & 23 & 1 & 25 & - & 35 & - & 10 & 2 & 114 & 3 & 117 \\
\hline City of Sukhum & 3 & - & - & 2 & - & - & 2 & - & 3 & - & 8 & 2 & 10 \\
\hline Total & 24 & - & 23 & 3 & 25 & - & 37 & - & 13 & 2 & 122 & 5 & 127 \\
\hline Total people & \multicolumn{2}{|c|}{24} & \multicolumn{2}{|c|}{26} & \multicolumn{2}{|c|}{25} & \multicolumn{2}{|c|}{37} & \multicolumn{2}{|c|}{15} & & & \\
\hline \multicolumn{14}{|c|}{ Mingrelia, districts: } \\
\hline Zugdidsky & 7 & 2 & 5 & - & 11 & 1 & 8 & - & 11 & - & 42 & 3 & 45 \\
\hline Lechkhumsky & 11 & 1 & 4 & 1 & 8 & - & $12^{54}$ & - & 4 & - & 39 & 2 & 41 \\
\hline Senaksky & 1 & - & 4 & - & 4 & 1 & 9 & 1 & 9 & 2 & 26 & 4 & 30 \\
\hline Total & 19 & 3 & 13 & 1 & 23 & 2 & 29 & 1 & 23 & 2 & 108 & 9 & 117 \\
\hline Total of people & \multicolumn{2}{|c|}{22} & \multicolumn{2}{|c|}{14} & \multicolumn{2}{|c|}{25} & \multicolumn{2}{|c|}{30} & \multicolumn{2}{|c|}{25} & & & \\
\hline
\end{tabular}

* The data also includes information on murdered newborn children.

B ased on: Sbornik statisticheskikh svedenii po Zakavkazskomu kraiu / ed. by E.Kondratenko. Ch. 1. Tiflis, 1902. P. 45, 46, 47, 48.

is partly because the majority of Circassians were already in Turkey, whereas Lezgins had not yet reached Abkhazia ${ }^{55}$.

For comparison, we can provide an example from the statistics on the Tiflis governorate that was located far from the Lezgin's area of activity. The Akhaltsikhe city and Akhaltsikhe uezd had a population of 69,664 people and 34 recorded murders in the period from 1894 to 1898 , which amounted to one murder per 2,048 people. Another illustration can be Guria (Ozurgetsky uezd). The population was 79,852 people, according to the 1897 census, while the number of murders was 21 . In total, it meant one murder per 3,802 people pr. $^{2}$.

The area of the Abkhazian principality hadn't changed from 1810 to 1864 and hadn't exceeded 5,805 sq. versts ${ }^{57}$. The figure is made up of the following data. The Sukhum Military Department had a territory of 6,941 sq. versts in $1865^{58}$. Also, it included Samurzakan with 1,136 sq. versts ${ }^{59}$, which was not part of Abkhazia. If we exclude the territory of Samurzakan, we can estimate the area of the Abkhazian principality.

Meanwhile, by the end of its existence, the Mingrelian principality had an area almost equal to that of Abkhazia - 5,898 sq. versts. However, by the time the Mingrelian prin-

55 The data published is mutually exclusive. One information records 4 people killed, and another -12 .

56 Ibid. P. $18,42,43$.

571 verst $=1,066$ meters.

58 Sbornik statisticheskikh svedenii o Kavkaze. P.7, 12; Kavkazskii kalendar' na 1868 god. Tiflis, 1868. P. 437.

59 Vychislenie ploshchadi Kavkazskogo kraia / ed. by podpolk. Vinnikov. St. Petersburg, 1905. P. 5. 
cipality had been incorporated into Russia, the area of Mingrelia, including Samurzakan, was about 7,034 sq. versts. This means that Mingrelia lost some of its territories from 1803 to 1867.

What were the demographic dynamics in this period? By $1865,53,421$ people lived in Abkhazia ${ }^{60}$. In the period from 1810 to 1865 , the population had grown from 23,5 thousand to 53421 people. In other words, the population was 2.2 times larger. At the same time, the population of Mingrelia together with Samurzakan numbered about 84 thousand people in 1803, and three districts of the former Mingrelian principality had 180,792 inhabitants in $1867^{61}$. In addition, there were 21,858 people in 1865 in Samurzakan, Mingrelia's former asset ${ }^{62}$. The overall figure was 202,650 people. Thus, the population of Mingrelia had increased by 2,4 times.

Summarizing the above findings, we can suggest the following major points:

1) Shikh Mansur's insurrection in 1785 triggered changes in the religious rules in Circassia and Abkhazia. The result was that Islam reached Abkhazia. At the time, the religion failed to become a widespread practice in Samurzakan and Mingrelia. For this reason, Samurzakan and Mingrelia remained Christian territories;

2) once the Abkhazian and Mingrelian principalities were incorporated into the Russian Empire, the ruling princes seriously overestimated the size of their populations. For example, the princes believed that the average household in their domains consisted of at least 9-10 people, while in reality it consisted of 4,7 people in Abkhazia and of about 7 people in Mingrelia;

3) the Abkhazian principality showed its first stages of decentralization; a process which was very typical of Circassian tribes and resulted in the emerging of independent social estates. In Mingrelia this process did not take place;

4) the integration by the Russian administration of the Samurzakan pristavstvo to the Sukhum Military Department in 1864 was intended to create an inter-confessional balance between strongly Islamized Abkhazia and Christian Samurzakan.

\section{References}

Byshkov P.A., Novitskaya L.Y., Artemova S.F. The evolution of social organization in Abkhazia and Samurzakano in 1810-1870. Bylye Gody, 2017, vol. 44, iss. 2, pp. 445-450.

Cherkasov A.A., Ivantsov V.G., Shmigel M., Molchanova V.S. Demographic characteristics of the Aristocratic Abkhazia in 1800-1860 years. Bylye Gody, 2016, vol. 39, iss. 1, pp. 53-66.

Cherkasov A. A., Ivantsov V.G., Smigel M., Molchanova V.S. The List of Captives from the Turkish Vessel Belifte as a Source of Information on the Slave Trade in the North-Western Caucasus in the Early $19^{\text {th }}$ century. Annales: Anali za istrske in mediteranske studije. Series historie et sociologia. 2017, vol. 27, iss. 4, pp. 851-864.

Cherkasov A. A., Menkovsky V. I., Ivantsov V. G., Ryabtsev A. A., Molchanova V.S., Natolochnaya O. V. The "Nobility" and "Commoners" in Ubykh Society: The Reasons behind the Social Conflict. Bulletin of the Georgian Academy of Sciences, 2014, vol. 8, no. 3, pp. 64-72.

\footnotetext{
${ }^{60}$ Sbornik statisticheskikh svedenii o Kavkaze. Vol. I. P. 39 Suppl.

${ }^{61}$ Ibid. P.7, 12.

${ }^{62}$ Ibid. P. 39. Suppl.
} 
Dzidzariya G. A. Narodnoe khozyaistvo i sotsial'nye otnosheniia v XIX v. (do krest'ianskoi reformy 1870 g.). Sukhumi, Abgiz Publ., 1958, 512 p. (In Russian)

Lapinskii T. Gortsy Kavkaza i ikh osvoboditel'naia bor'ba protiv russkikh. Nal'chik, Izdatel'skii tsentr El'-Fa Publ., 1995, 455 p. (In Russian)

Peisonel' M. Issledovanie torgovli na cherkessko-abkhazskom beregu Chernogo morya v 1750-1762 gg. Krasnodar, Obschestvo izucheniia Adygeiskoi avtonomnoi oblasti Publ., 1927, 35 p. (In Russian)

Shevchenko N. A., Vidishcheva E. V., Emelyanova O. V. The Establishment of the System of Public Education in the Caucasus (1802-1917 years): the Characteristic Features. Bylye Gody, 2016, vol.40, iss.2, pp. 363-372.

Vazerova A.G., Gurbanov R. A., Micky N.V. The Crimean War (1855-1856): the Combat Operations in Rioni Region. Bylye Gody, 2017, vol. 43, iss. 1, pp.112-120. (In Russian)

Received: June 6, 2018 Accepted: September 10, 2018 